\title{
Mechanical Strain of Rat Vascular Smooth Muscle Cells Is Sensed by Specific Extracellular Matrix/Integrin Interactions
}

\author{
Emily Wilson, Krishnankutty Sudhir, and Harlan E. Ives \\ Division of Nephrology and Cardiovascular Research Institute, University of California, San Francisco, California 94143
}

\begin{abstract}
Cyclic mechanical strain $(1 \mathrm{~Hz}$ ) causes a mitogenic response in neonatal rat vascular smooth muscle cells due to production and secretion of PDGF. In this study, the mechanism for sensing mechanical strain was investigated. Silicone elastomer strain plates were coated at varying densities with elastin, laminin, type I collagen, fibronectin, or vitronectin. Strain was applied by cyclic application of a vacuum under the dishes. Cells adhered, spread, and proliferated on each matrix protein, but the mitogenic response to strain was matrix dependent. Strain increased DNA synthesis in cells on collagen, fibronectin, or vitronectin, but not in cells on elastin or laminin. When strain was applied on matrices containing both laminin and vitronectin, the mitogenic response to strain depended upon the vitronectin content of the matrix. Fibronectin, in soluble form $(0-50 \mu \mathrm{g} / \mathrm{ml})$, and the integrin binding peptide GRGDTP $(100 \mu \mathrm{g} / \mathrm{ml})$ both blocked the mitogenic response to mechanical strain in cells grown on immobilized collagen. Neither soluble laminin nor the inactive peptide GRGESP blocked the response to strain. GRGDTP did not alter the mitogenic response to exogenous PDGF or $\alpha$-thrombin but did prevent the secretion of PDGF in response to strain. Furthermore, GRGDTP, but not GRGESP, prevented strain-induced expression of a PDGFA chain promoter 890 bp-chloramphenicol acetyltransferase construct that was transiently transfected into vascular smooth muscle cells. Finally, the response to strain was abrogated by antibodies to both $\beta_{3}$ and $\alpha_{v} \beta_{5}$ integrins but not by an antibody to $\beta_{1}$ integrins. Thus interaction between integrins and specific matrix proteins is responsible for sensing mechanical strain in vascular smooth muscle cells. $(J$. Clin. Invest. 1995. 96:2364-2372.) Key words: mechanical strain • RGD peptides • extracellular matrix • platelet-derived growth factor $\cdot$ gene regulation
\end{abstract}

\section{Introduction}

Vascular smooth muscle (VSM) ${ }^{1}$ cells in situ are constantly exposed to cyclic mechanical strain. Alterations in blood flow

Address correspondence to Harlan E. Ives, Director, Division of Nephrology, 672 Health Sciences East, Box 0532, University of California, San Francisco, San Francisco, CA 94143. Phone: 415-476-2172; FAX: 415-476-3381.

Received for publication 9 January 1995 and accepted in revised form 12 July 1995.

1. Abbreviations used in this paper: CAT, chloramphenicol acetyltransferase; ECM, extracellular matrix; VSM, vascular smooth muscle.

J. Clin. Invest.

(C) The American Society for Clinical Investigation, Inc.

0021-9738/95/11/2364/09 \$2.00

Volume 96, November 1995, 2364-2372 and pressure are thought to play an important role in the development of the vasculature and adaptation of adult blood vessels (1). Mechanical forces may also contribute to the pathologic alterations of the vessel wall in hypertension $(2,3)$. The effect of mechanical forces on the growth and differentiated properties of cells in vitro is not well understood. Little is known about how individual cells respond to mechanical strain or the underlying molecular mechanisms by which mechanical events are transduced into physiological responses.

Methods have recently been developed to subject cells to mechanical strain in vitro $(4,5)$. Using a device which imparts strain by application of a vacuum to silicone elastomer plates, Sumpio et al. (6) reported that VSM cells alter their orientation in response to mechanical strain. Using a similar device, our laboratory showed that cyclic mechanical strain induces DNA synthesis in VSM cells via the autocrine production of PDGF (7) and that the mitogenic potential of angiotensin II and $\alpha$ thrombin are enhanced by mechanical strain (8). Additionally, our group showed that exposure of VSM cells to mechanical strain alters the expression patterns of smooth muscle and nonmuscle myosin (9). These studies taken collectively suggest that VSM cells respond to mechanical strain with complex changes in both DNA synthesis and expression of specific gene products.

Physical forces can lead to changes in gene expression that are important both in normal development and in pathological conditions. Werb and co-workers have shown that shape changes can induce or suppress the expression of metalloproteinases (10). Gimbrone and co-workers have found in endothelial cells that the PDGF-B gene is induced by fluid shear stress via a specific DNA response element (11).

How cells sense mechanical perturbations is not known. It has been shown that mechanical forces can activate adenylyl cyclase (12-14), phospholipase $C(15,16)$, and activate mechanosensitive ion channels (17). Ingber proposed that interaction of extracellular matrix (ECM) proteins with their integrin receptors plays a central role in transmitting mechanical signals to and from the cytoskeleton (18). Wang et al. showed that magnetic beads coated with RGD peptides are capable of transferring mechanical stress to the cytoskeleton (19). Stretching of a flexible culture substratum leads to altered cytoskeletal organization in some systems (6), and shear stress causes focal adhesions to reorganize in endothelial cells (20). Whether or not the cytoskeleton (through its interaction with integrins and the ECM) participates in signal generation after mechanical perturbation remains unknown.

In this study we examined the role of the ECM-integrin interaction in the ability of VSM cells to increase PDGF secretion and DNA synthesis in response to mechanical strain. We found that particular matrix proteins, when immobilized on deformable surfaces, are necessary to confer this response to strain. Soluble matrix proteins, RGD peptides, and certain antiintegrin antibodies block the response. Thus, the ability of VSM 
cells to sense mechanical strain is dependent on the interaction between specific integrins and the extracellular matrix subjected to strain.

\section{Methods}

Materials. All materials were purchased from Sigma Chemical Co. (St. Louis, MO) unless otherwise specified. BSA was fraction V, fatty acid poor (Miles Scientific Div., Miles Laboratories, Inc., Naperville, IL). $\left[{ }^{3} \mathrm{H}\right]$ thymidine and $\left[{ }^{14} \mathrm{C}\right]$ acetyl-CoA were from New England Nuclear/ Du Pont (Wilmington, DE). Flex plates were from Flexcell Corp. (McKeesport, PA). Peptides GRGDTP and GRGESP were purchased from GIBCO-BRL Gaithersburg, MD. Highly purified $\alpha$-thrombin was generously supplied by John W. Fenton II (Albany Medical College of Union University, Albany, NY) and PDGF-BB was purchased from GIBCO BRL. $\beta$-galactosidase assay kit was purchased from Promega Corp. (Madison, WI). Bolton-Hunter reagent was obtained from ICN Radiochemicals Div., ICN Biomedical Inc. (Irvine, CA). A function-blocking antibody to rat $\beta_{3}$ integrin was obtained from PharMingen (San Diego, CA). Anti-human $\alpha_{\mathrm{v}} \beta_{5}$ (P1F6) (21) and $\alpha_{\mathrm{v}}$ (H5P10) were obtained from Dr. Dean Sheppard (University of California, San Francisco). Anti- $\beta_{1}$ was obtained from Dr. Donna Mendrick (Harvard University, Cambridge, MA).

Cell culture. Primary cultures of VSM cells from newborn rats were established by Peter Jones (University of Southern California, Los Angeles, CA). From these primary cultures the R22 D cell line was established (22) and generously supplied to us by Dr. Jones at passage 15. The cells were maintained in MEM with $10 \%$ FBS, $2 \%$ tryptose phosphate broth, penicillin $(50 \mathrm{U} / \mathrm{ml})$, and streptomycin $(50 \mathrm{U} / \mathrm{ml})$ in a humidified atmosphere of $5 \% \mathrm{CO}_{2}$ at $37^{\circ} \mathrm{C}$. Culture medium was changed every other day until confluent. Cells were subcultured with trypsin-versene. Cells were used from passages 16-29 for these studies.

Application of cyclic strain to cultured cells. For most experiments, cells were grown to confluence in six-well collagen-coated silicone elastomer-bottomed culture plates (Flex I; Flexcell Corp.). Cells were subjected to mechanical deformation with the Flexercell Stress Unit (Flexcell Corp.). The stress unit is a modification of the unit initially described by Banes and co-workers $(4,5)$ and consists of a computercontrolled vacuum unit and a base plate to hold the culture dishes. Vacuum $(15-20 \mathrm{kPa})$ is repetitively applied to the rubber-bottomed dishes via the base plate which is placed in a humidified incubator with $5 \% \mathrm{CO}_{2}$ at $37^{\circ} \mathrm{C}$. The computer system controls the frequency of deformation and the negative pressure applied to the culture plates.

Coating of plates with extracellular matrix proteins. Extracellular matrix proteins were applied to the silicone elastomer by adsorption. Solutions containing collagen $\left(6 \mu \mathrm{g} / \mathrm{cm}^{2}\right)$, poly-L-lysine $\left(10 \mu \mathrm{g} / \mathrm{cm}^{2}\right)$, fibronectin $\left(5 \mu \mathrm{g} / \mathrm{cm}^{2}\right)$, elastin $\left(10 \mu \mathrm{g} / \mathrm{cm}^{2}\right)$, laminin $\left(2 \mu \mathrm{g} / \mathrm{cm}^{2}\right)$, or vitronectin $\left(0.005-5.0 \mu \mathrm{g} / \mathrm{cm}^{2}\right)$ were placed in the dishes and allowed to air dry overnight. For plates with mixed matrices containing laminin and vitronectin, commercial plates coated with laminin $\left(10^{14} \mathrm{sites} / \mathrm{cm}^{2}\right.$, Flexcell Corp.) were coated with various quantities of vitronectin as described above. All plates were washed with PBS, followed by BSA $\left(1 \mathrm{mg} / \mathrm{ml}\right.$ to block uncoated sites on the silicone) for $1 \mathrm{~h}$ at $37^{\circ} \mathrm{C}$. The plates were then rinsed with culture medium to remove unadsorbed protein. Efficiency of protein adsorption was determined with ${ }^{125} \mathrm{I}$-labeled matrix proteins. Matrix proteins were iodinated using BoltonHunter reagent obtained from ICN. Proteins were labeled using modifcations of the protocol originally described by Bolton and Hunter (23). The proteins were suspended in phosphate buffer $(\mathrm{pH} 7.5)$ at a concentration of $1 \mathrm{mg} / \mathrm{ml}$ and reacted with the labeling reagent for $2 \mathrm{~h}$ at $0^{\circ} \mathrm{C}$. Unreacted reagent was separated from the labeled protein by gel filtration chromatography with disposable column (10 DG; Bio Rad Laboratories, Richmond, CA). The radio specific activity of the protein solution was calculated and used to estimate the amount of adsorbed protein.

$\left[{ }^{3} \mathrm{H}\right]$ Thymidine incorporation. Cells were grown in six-well Flex plates until confluent and were growth arrested by placing them in "quiescence" medium containing $5 \mathrm{mg} / \mathrm{ml}$ transferrin and $0.5 \mathrm{mg} / \mathrm{ml}$
BSA for $72 \mathrm{~h}$. For measurement of $\left[{ }^{3} \mathrm{H}\right]$ thymidine incorporation into DNA, $1 \mathrm{mCi} / \mathrm{ml}$ of $\left[{ }^{3} \mathrm{H}\right]$ thymidine was added to the growth medium of each well and incubated at $37^{\circ} \mathrm{C}$ for $6 \mathrm{~h}$. Cells were then washed three times with assay medium $(140 \mathrm{mM} \mathrm{NaCl}, 5 \mathrm{mM} \mathrm{KCl}, 2 \mathrm{mM}$ $\mathrm{CaCl}_{2}, 1 \mathrm{mM} \mathrm{Na} \mathrm{HPO}_{4}, 25 \mathrm{mM}$ glucose, $25 \mathrm{mM}$ Hepes/ $\mathrm{NaOH}, \mathrm{pH}$ 7.20 , and $0.5 \mathrm{mg} / \mathrm{ml} \mathrm{BSA}$ ) and extracted with $15 \%$ TCA at $4^{\circ} \mathrm{C}$ for at least $30 \mathrm{~min}$. The rubber bottom of the Flex plates containing the TCAprecipitable material was washed with water, removed from the plate, and placed directly into a scintillation vial for counting (7).

Cell number and morphology. Determinations of cell number were made using a hemocytometer on tryspinized cell preparations. After subjecting the cells to the described protocol, medium was removed, and the cells were washed extensively with PBS. The cells were then fixed for 5 min with $100 \%$ methanol. The methanol was removed and the silicone membranes were allowed to air dry. The cells were stained with Giemsa (Sigma Chemical Co.) for $5 \mathrm{~min}$ and then washed with distilled water. The cells were then examined and photographed using bright-field microscopy with an inverted microscope (Nikon Inc., Melville, NY).

Analysis of PDGF-A chain promoter activity. A PDGF-A chain promoter $890 \mathrm{bp}$-chloramphenicol acetyltransferase (CAT) construct was obtained from Tucker Collins (Harvard University, Cambridge, MA) (24). The construct was cotransfected with a plasmid containing the constitutively expressed Rous sarcoma virus- $\beta$-galactosidase. Transfection was accomplished using DEAE-dextran with chloroquine (25). The cells were allowed to recover for $24 \mathrm{~h}$ in complete medium and were then transferred to quiescence medium and subjected to $24 \mathrm{~h}$ of mechanical strain. CAT activity was measured by a modification of the method of Sleigh (26). Cells were lysed with lysis buffer (Reporter; Promega Corp.). The resulting lysates were added to assay buffer containing $\left[{ }^{14} \mathrm{C}\right]$ acetyl-CoA $(0.02 \mathrm{mCi}, 0.5 \mathrm{mM})$ and unlabeled chloramphenicol $(1.6 \mathrm{mM})$. The mixtures were incubated at $37^{\circ} \mathrm{C}$ for $1-4 \mathrm{~h}$. The lysates were extracted with ethyl acetate. The organic phase was counted in a scintillation counter. Cell lysates were normalized to adjust for transfection efficiencies by adding equal amounts of $\beta$-galactosidase activity (assay kit; Promega Corp.). Mock transfections were performed to determine background.

Flow cytometry. Cells were harvested in saline/trypsin/versene $(0.05 \%$ trypsin $)$ and were incubated in normal goat serum for $10 \mathrm{~min}$ at $4^{\circ} \mathrm{C}$ to inactivate trypsin and to block nonspecific binding. Cells were pelleted, resuspended in PBS, and incubated with the integrin antibodies (mouse) for $20 \mathrm{~min}$ on ice. Medium was aspirated, cells were washed with PBS and incubated with phycoerythrin-conjugated anti-mouse IgG $\left(\mathrm{H}+\mathrm{L} \mathrm{F}\left(\mathrm{ab}^{\prime}\right) 2\right.$, Boehringer Mannheim Biochemicals, Indianapolis, IN $)$ secondary antibody. Cells were washed and resuspended in PBS and subjected to flow cytometric analysis using a FACScan ${ }^{\circ}$ (Becton Dickinson and Co., San Jose, CA [21]).

\section{Results}

Extracellular matrix composition determines the mitogenic re sponse of vascular smooth muscle cells to mechanical strain. The role of specific ECM molecules in conferring the mitogenic response of VSM cells to mechanical strain was examined. Silicone elastomer culture plates were coated with various ECM molecules by adsorption. The number of matrix molecules adherent to the silicone plates was determined using ${ }^{125}$ I-labeled proteins and was $\sim 10^{12} \mathrm{sites} / \mathrm{cm}^{2}$ for collagen, fibronectin, and laminin. For vitronectin, the number of sites was varied between $5 \times 10^{9}$ and $2 \times 10^{12}$ by adjusting the quantity of protein adhered to the plates (Table I). Control cells not subjected to mechanical strain were grown on similar silicone plates coated with the same matrix components. All cells were plated in serum-free medium and allowed to adhere for $12 \mathrm{~h}$ before initiation of mechanical strain. Thymidine incorporation was determined after 48-h exposure to cyclic mechanical strain. Cells 
Table I. Site Density of Matrix Proteins Adsorbed to Silicone Elastomer Dishes

\begin{tabular}{lcc}
\hline ECM component & Coating density & Sites $/ \mathrm{cm}^{2}$ \\
\hline & $\mu g / \mathrm{cm}^{2}$ & $n$ \\
Collagen (type I) & 6.0 & $1 \times 10^{12}$ \\
Fibronectin & 5.0 & $2 \times 10^{12}$ \\
Laminin & 2.0 & $1 \times 10^{12}$ \\
Vitronectin & 0.005 & $5 \times 10^{9}$ \\
& 0.05 & $6 \times 10^{10}$ \\
& 0.5 & $4 \times 10^{11}$ \\
& 5.0 & $2 \times 10^{12}$
\end{tabular}

Purified matrix proteins were labeled with ${ }^{125} \mathrm{I}$ and the radiospecific activity was calculated. Except where indicated, $5 \mu \mathrm{g} / \mathrm{cm}^{2}$ of the matrix proteins was adsorbed to the silicone elastomer plates (see Methods). After adsorption, blocking with BSA, and washing (see Methods), plates were counted to determine the number of adsorbed sites of the indicated proteins.

plated on dishes with no coating, poly-L-lysine, elastin, or laminin showed no significant response to mechanical strain (Fig. $1 \mathrm{~A}$ ). In contrast, cells plated on collagen or fibronectin responded with dramatic increases in thymidine incorporation of 3.7- and 8.2-fold, respectively. Cells plated on vitronectin also exhibited a significant mitogenic response to mechanical strain (Fig. $1 B$ ). For vitronectin, we examined the effect of coating

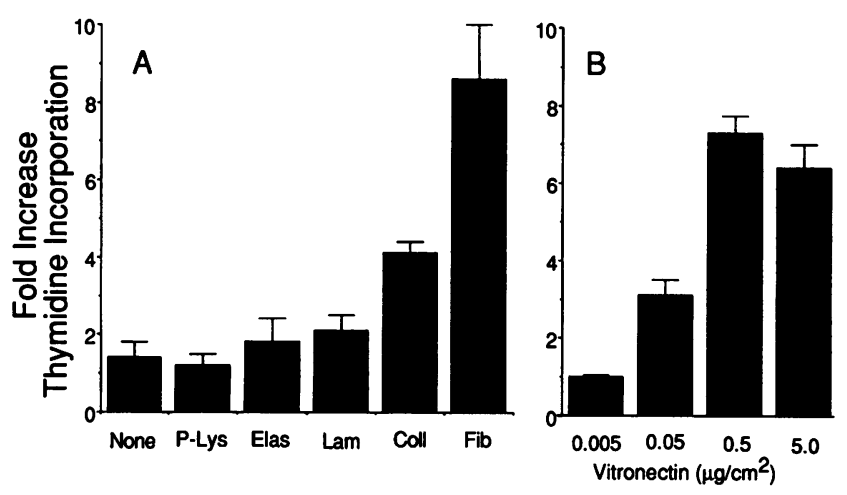

Figure 1. Effect of extracellular matrix proteins on mitogenic response to strain. (A) VSM cells were plated on Flex I (carboxyl surface) strain plates that were coated with nothing (None), poly-L-lysine ( $P$-Lys), elastin (Elas), laminin (Lam), type I collagen (Coll), or fibronectin (Fib) at the densities indicated in Methods. (B) Plates were coated with vitronectin at the indicated densities. Cells were plated in serum-free medium and allowed to adhere to the dishes overnight. Medium was changed and cells were exposed to cyclic strain or no strain for $48 \mathrm{~h}$. $\left[{ }^{3} \mathrm{H}\right]$ thymidine was added to each well $6 \mathrm{~h}$ before harvest. $\left[{ }^{3} \mathrm{H}\right]-$ Thymidine incorporation into DNA was determined as described in Methods. Basal thymidine incorporation levels were $(A)$ 1,505 \pm 158 (no coating), 765 \pm 82 (poly-L-lysine), 4,205 \pm 310 (elastin), $8,253 \pm 425$ (laminin), 3,525 \pm 210 (collagen), 1,575 \pm 107 (fibronectin). Basal (nonstrain) thymidine incorporation in $(B)$ was $1,235 \pm 218$ (vitronectin, $0.005 \mu \mathrm{g} / \mathrm{cm}^{2}$ ), 2,740 $\pm 210\left(0.05 \mu \mathrm{g} / \mathrm{cm}^{2}\right), 5,272 \pm 38(0.5$ $\left.\mu \mathrm{g} / \mathrm{cm}^{2}\right)$, and $6,140 \pm 475\left(5.0 \mu \mathrm{g} / \mathrm{cm}^{2}\right)$. Data are presented as the fold increase in thymidine incorporation of cells subjected to strain as compared to unstrained cells on the same surface coating. Data are the mean \pm SE for triplicate determinations in one of two similar experiments.
Table II. Site Density of Vitronectin Adhered to Laminin-coated silicone Elastomer Dishes

\begin{tabular}{cc}
\hline Vitronectin density & Sites $/ \mathrm{cm}^{2}$ \\
\hline$\mu \mathrm{g} / \mathrm{cm}^{2}$ & $n$ \\
0.005 & $8 \times 10^{9}$ \\
0.05 & $1 \times 10^{11}$ \\
0.5 & $9 \times 10^{11}$ \\
5 & $5 \times 10^{12}$ \\
\hline
\end{tabular}

Purified vitronectin was labeled with ${ }^{125} \mathrm{I}$ and the radiospecific activity was calculated. Vitronectin, at the indicated concentrations, was adsorbed to silicone elastomer plates containing $10^{14} \mathrm{sites} / \mathrm{cm}^{2}$ laminin (see Methods). After adsorption, blocking, and washing, plates were counted to determine the number of adsorbed vitronectin sites.

density on mitogenic response to strain. Response increased with vitronectin density and appeared to saturate at densities higher than $0.5 \mu \mathrm{g} / \mathrm{cm}^{2}\left(4 \times 10^{11}\right.$ sites $\left./ \mathrm{cm}^{2}\right)$.

The failure of strain to generate a mitogenic response on laminin was not due to a general loss of mitogenic responses on this matrix protein. Cells cultured on laminin exhibited a 19-fold increase in thymidine incorporation (from 2,875 \pm 345 to $48,650 \pm 1,270 \mathrm{cpm} /$ dish) in response to a mixture of PDGF $(10 \mathrm{ng} / \mathrm{ml})$ and thrombin $(1.5 \mathrm{nM})$. In cells plated on mixed matrices containing an excess of laminin with varying densities of vitronectin (Table II), cells exhibited an increasing mitogenic response to strain as a function of the vitronectin content of the matrix (Fig. 2). Thus, cells fail to respond to strain when plated on pure laminin-coated dishes but do respond to growth factors on this matrix. More importantly, cells also respond to strain on laminin if small quantities of vitronectin are added to the laminin matrix.

To determine whether the different matrix proteins altered the ability of the cells to adhere to the plates or to spread normally, cell number and morphology were examined for cells on each substrate. Cells added to plates with no coating or polyL-lysine adhered to the plates but failed to spread (data not shown). Cells plated on laminin, collagen, and fibronectin attached to the dishes with approximately equal efficiency ( $\mathrm{Ta}$ ble III). As expected from the thymidine data, cell number

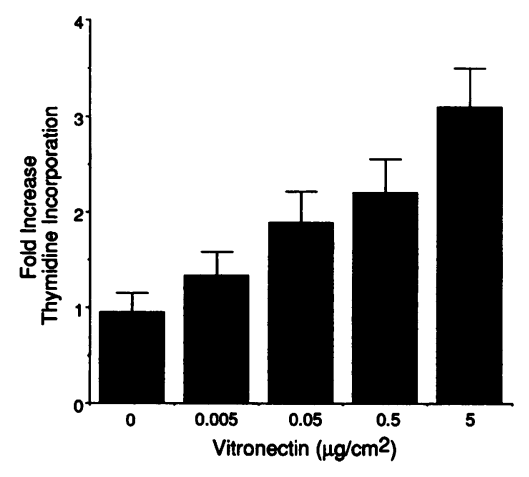

Figure 2. Effect of mixed laminin/vitronectin matrices on mitogenic response to strain. VSM cells were plated on silicone elastomer dishes with mixed matrices containing laminin and vitronectin (Table II) After exposure to $48 \mathrm{~h}$ strain, fold thymidine incorporation was determined as in Fig. 1. Basal (nonstrain) thymidine

incorporations were $450 \pm 35$ (control), $417 \pm 27\left(0.005 \mu \mathrm{g} / \mathrm{cm}^{2}\right.$, vitronectin $), 437 \pm 42\left(0.05 \mu \mathrm{g} / \mathrm{cm}^{2}\right), 538 \pm 57\left(0.5 \mu \mathrm{g} / \mathrm{cm}^{2}\right)$, and $612 \pm 52\left(5.0 \mu \mathrm{g} / \mathrm{cm}^{2}\right) \mathrm{cpm} /$ dish. 
Table III. Effect of ECM Proteins on Initial Adhesion and Strain-induced Growth

\begin{tabular}{lcccr}
\hline \multicolumn{1}{c}{ Coating } & Baseline & No strain & Strain & $\begin{array}{r}\text { Percent } \\
\text { increase }\end{array}$ \\
\hline & \multicolumn{5}{c}{ Cell number $\times 10^{-4}$} \\
Laminin & $2.6 \pm 0.03$ & $3.0 \pm 0.02$ & $3.1 \pm 0.04$ & 3 \\
Collagen & $3.7 \pm 0.04$ & $4.1 \pm 0.05$ & $4.9 \pm 0.03$ & 20 \\
Fibronectin & $4.3 \pm 0.05$ & $4.7 \pm 0.04$ & $6.3 \pm 0.05$ & 34 \\
& & & & \\
\hline
\end{tabular}

$1.5 \times 10^{5}$ cells in serum-free media were plated on strain plates coated with the indicated proteins. $12 \mathrm{~h}$ later, baseline cell number was determined. After addition of fresh serum-free media, cells were either subjected to $48 \mathrm{~h}$ of mechanical strain $(1 \mathrm{~Hz})$ or no strain. Percent increase represents change in cell number due to strain on each matrix protein. Data presented as mean $\pm S E$ of triplicate determinations.

increased to a greater extent in response to strain on fibronectin than on the other substrates (Table III). Although morphological appearance varied to some degree on these substrates, the cells rapidly attached and spread on all of them (Fig. 3). Furthermore, $48 \mathrm{~h}$ of mechanical strain did not grossly alter their morphology. Thus, the dramatic differences in response to mechanical strain shown in Fig. 1 and Table III cannot be explained simply by the failure of cells to adhere to particular matrix proteins. Rather, specific matrix-cell interactions must be involved in transmitting mechanical signals to the cell. We therefore attempted to interrupt the response to mechanical strain by perturbing the matrix-integrin interaction with soluble proteins and peptides.

Soluble matrix proteins or peptides perturb the ability of VSM cells to sense mechanical strain. Since cells adhered to fibronectin-coated plates showed the largest increases in $\left[{ }^{3} \mathrm{H}\right]$ thymidine incorporation in response to strain, we asked whether fibronectin would interfere with the response to strain if present in the soluble form rather than adherent to the dishes. Soluble fibronectin $(1-100 \mu \mathrm{g} / \mathrm{ml})$ was added to both control and strained VSM cells that were plated on collagen-coated silicone plates (Fig. $4 A$ ). In the absence of soluble fibronectin, strain increased thymidine incorporation by 3.1 -fold. Soluble fibronectin $(25 \mu \mathrm{g} / \mathrm{ml})$ blocked the response to strain on collagencoated plates by $>90 \%$ (closed circles, Fig. $4 A$ ). This inhibitory effect of soluble fibronectin was dose dependent, with $50 \%$ inhibition at $10 \mu \mathrm{g} / \mathrm{ml}$. Unstrained cells were not affected by soluble fibronectin (open circles, Fig. $4 \mathrm{~A}$ ). This inhibition of the mitogenic response to strain by soluble fibronectin contrasts

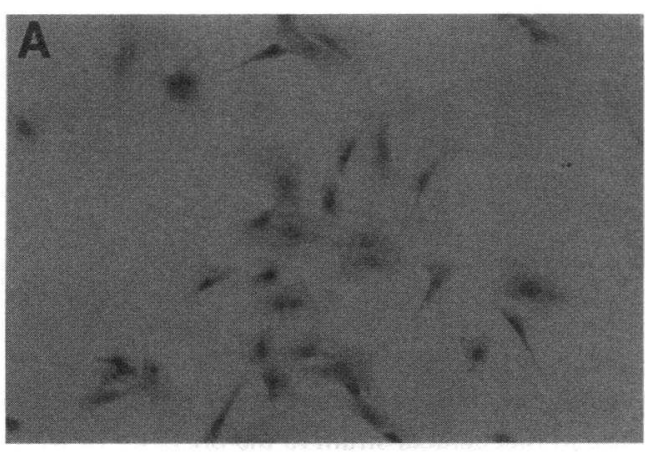

fibronectin (no strain)

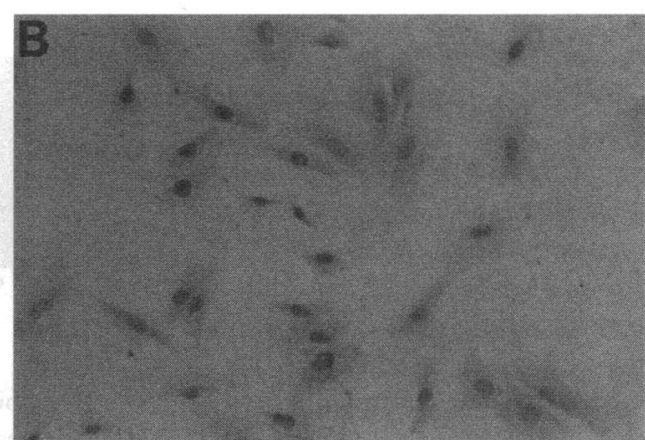

fibronectin (+ strain)

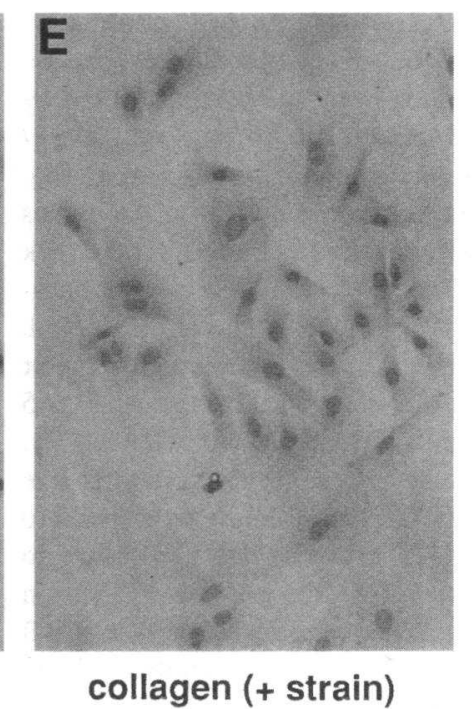

collagen (+ strain)

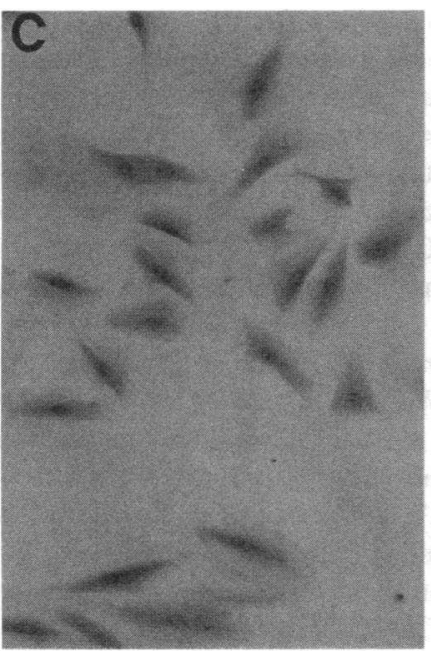

laminin (+ strain)

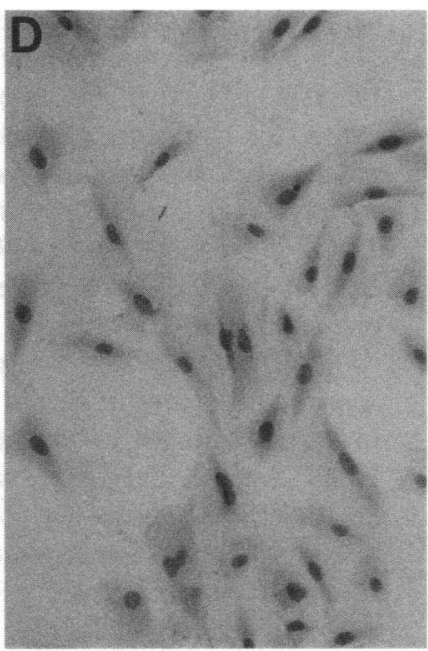

elastin (+ strain)

Figure 3. Effect of mechanical strain and extracellular matrix on cell morphology. VSM cells were plated in serum-free medium on silicone elastomer dishes that were coated with fibronectin and subjected to no strain $(A)$ or strain $(B)$ for $48 \mathrm{~h}$. VSM cells plated on laminin $(C)$, elastin $(D)$, or collagen $(E)$ were subjected to mechanical strain $(48 \mathrm{~h})$. Cells were fixed and stained as described in Methods. $\times 120$. 

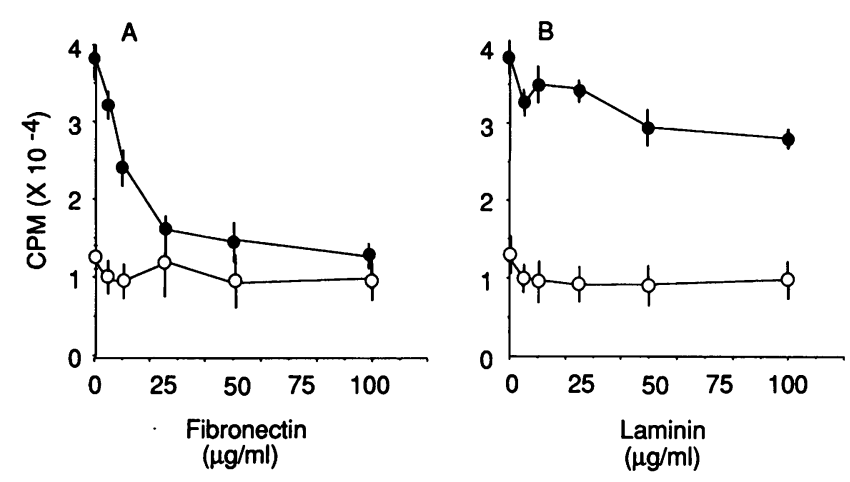

Figure 4. Soluble fibronectin inhibits strain-induced DNA synthesis. Cells were plated on collagen-coated silicone elastomer membranes, grown to confluence, and then placed in quiescence medium (see Methods) for $72 \mathrm{~h}$. ( $A$ ) Soluble fibronectin or $(B)$ soluble laminin was added to the medium at the indicated concentrations and the cells were subjected to either $48 \mathrm{~h}$ of mechanical strain (closed circles) or no strain (open circles). $\left[{ }^{3} \mathrm{H}\right]$ Thymidine incorporation was measured as described in Methods. The data are the mean \pm SE for triplicate determinations of one of two similar experiments.

markedly with the enhancement of the response observed when fibronectin was fixed to the stretch plates (Fig. 1).

Soluble laminin over the same concentration range used for fibronectin (Fig. $4 \mathrm{~B}$ ) did not significantly affect the mitogenic response to strain on collagen-coated plates. Therefore, unlike fibronectin, laminin did not affect the mitogenic response whether soluble or fixed to the dishes.

To further test the involvement of matrix-integrin interactions in transducing the growth response to mechanical strain, we examined the effect of an integrin-binding peptide GRGDTP $(100 \mu \mathrm{g} / \mathrm{ml})$ on strain-induced DNA synthesis (27). Addition of GRGDTP to the medium before the start of mechanical strain completely blocked the strain-induced increase in DNA synthesis (Fig. $5 A$ ). The strain-induced increase in cell number was also blocked by GRGDTP (cell number on control dishes increased from $2.6 \times 10^{5}$ to $4.0 \times 10^{5}$ after $48 \mathrm{~h}$ strain but was unchanged in the presence of GRGDTP $(100 \mu \mathrm{g} / \mathrm{ml})$. At concentrations of 10-50 $\mu \mathrm{g} / \mathrm{ml}$, GRGDTP caused lesser, dosedependent reductions in strain-induced thymidine incorporation (data not shown). Thymidine incorporation was unaffected by the inactive control peptide GRGESP $(100 \mu \mathrm{g} / \mathrm{ml})$. At $100 \mu \mathrm{g} /$ $\mathrm{ml}$, GRGDTP caused only minor changes in cell shape (Fig. 6), making it unlikely that the failure to respond to strain was due to loss of contact with the substratum. Moreover, the lack of response to strain in the presence of GRGDTP was not artifactually due to detachment of cells during the strain period. Only a tiny fraction of the cells was found in the medium after the strain period in either the absence or presence of RGD (55 cells/dish, control strain; 69 cells/dish, strain with GRGDTP).

Since strain-induced DNA synthesis in this system is due to autocrine production of PDGF (7), the failure to respond to strain in the presence of GRGDTP could be due to a failure to respond to PDGF or a failure to synthesize or secrete PDGF in response to strain. The mitogenic response to either PDGF-BB (10 $\mathrm{ng} / \mathrm{ml}$ ) or $\alpha$-thrombin ( $1 \mathrm{U} / \mathrm{ml}$ ) was unaffected by GRGDTP $(100 \mu \mathrm{g} / \mathrm{ml})$ or GRGESP $(100 \mu \mathrm{g} / \mathrm{ml})$ (Fig. 5, $B$ and $C$ ). This finding suggested that GRGDTP interferes with the production or secretion of PDGF (or other growth factors) in response to strain.
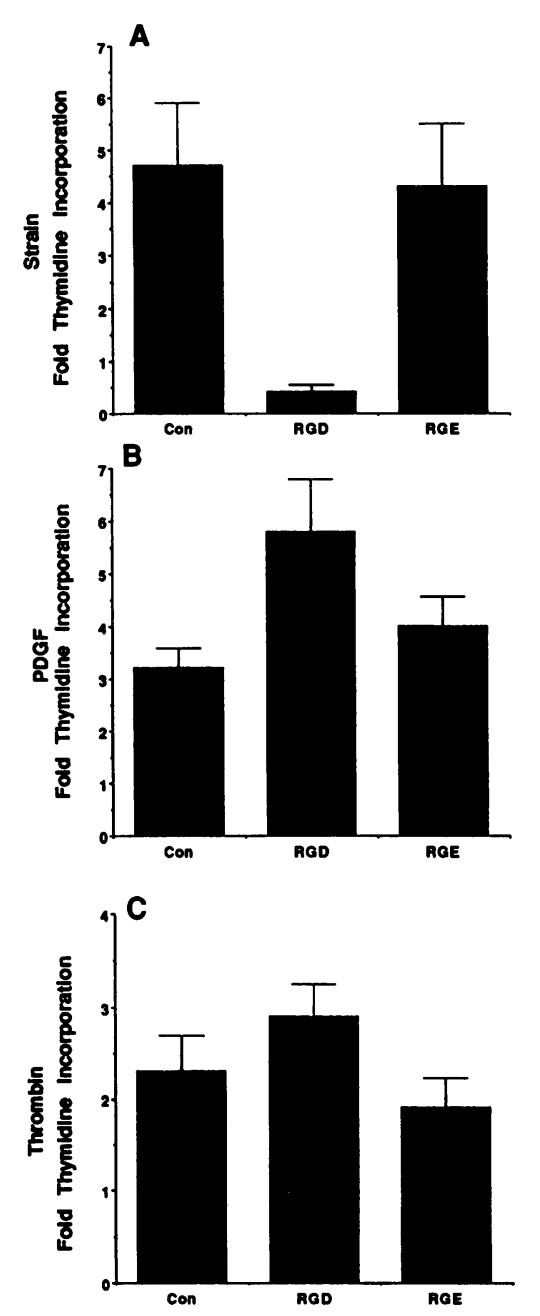

Figure 5. RGD peptides specifically block straininduced $\left[{ }^{3} \mathrm{H}\right]$ thymidine incorporation. In three separate experiments, the effects of the peptides GRGDTP $(100 \mu \mathrm{g} / \mathrm{ml})$ (RGD), GRGESP ( 100 $\mu \mathrm{g} / \mathrm{ml})(R G E)$, or no peptide (Con) on mitogenic response to $48 \mathrm{~h}$ of mechanical strain $(A)$, PDGF-BB ( $10 \mathrm{ng} / \mathrm{ml}, 24$ h) (B), or $\alpha$-thrombin ( 8 $\mathrm{nM} / \mathrm{ml}, 24 \mathrm{~h})(\mathrm{C})$ were analyzed. $\left[{ }^{3} \mathrm{H}\right]-$

Thymidine was added for the final $6 \mathrm{~h}$ of each incubation. Data presented as fold increase in $\left[{ }^{3} \mathrm{H}\right]-$ thymidine incorporation over cells not receiving the indicated mitogenic stimulus. Data are the mean $\pm S E$ for triplicate determinations in one of two similar experiments.

The ability of the cells to secrete PDGF or other growth factors in response to mechanical strain in the presence of RGD peptide was tested by transferring conditioned medium from strained and unstrained cells to unstrained PDGF-responsive cells (Table IV). Conditioned medium from the strained cells $(48 \mathrm{~h}, 1 \mathrm{~Hz})$ produced a 1.7 -fold increase in thymidine incorporation in test cells when compared with medium from unstrained cells. This mitogenic response to the conditioned medium was absent when the medium was taken from strained cells exposed to GRGDTP (Table IV). Since the cells remain responsive to PDGF in the presence of GRGDTP (Fig. 5 B), these findings suggest that GRGDTP prevents the strain-induced production or secretion of PDGF.

$R G D$ peptide blocks expression of PDGF-A gene in response to mechanical strain. We next asked whether GRGDTP interferes with the ability of mechanical strain to induce the PDGF-A gene. Cells were transiently transfected with a fulllength PDGF-A promoter CAT construct and then exposed to mechanical strain in the presence or absence of RGD peptides. Mechanical strain caused a threefold increase in CAT activity in the control cells (Fig. 7). GRGDTP, but not GRGESP, significantly blunted the strain-induced increase in CAT activity (Fig 7). Thus the failure of cells to exhibit a mitogenic response to mechanical strain in the presence of GRGDTP appears to result from a failure to induce PDGF gene transcription under these conditions. 


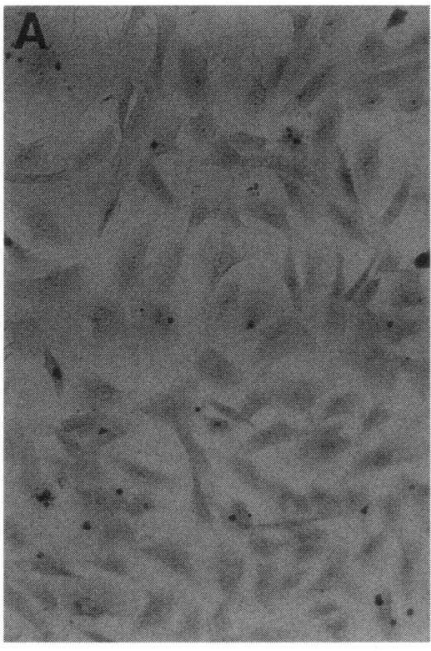

control (+ strain)

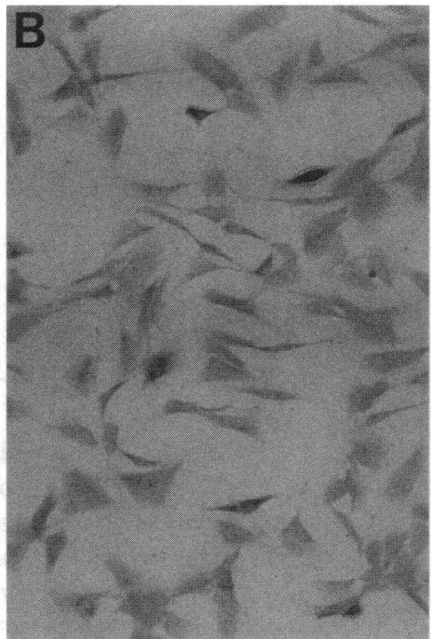

GRGDTP (+ strain)

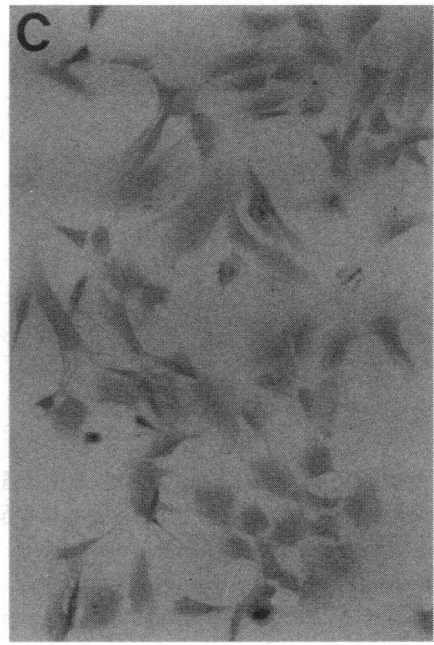

GRGESP (+strain)

Figure 6. Effect of GRGDTP on morphology of strained cells. Quiescent cultures of VSM cells on collagen-coated silicone elastomer plates were treated with vehicle $(A)$, GRGDTP $(100 \mu \mathrm{g} / \mathrm{ml})(B)$, or GRGESP $(100 \mu \mathrm{g} / \mathrm{ml})(C)$ and subjected to mechanical strain $(48 \mathrm{~h})$. Cells were fixed and stained as described in Methods. $\times 120$.

Antibodies to fibronectin/vitronectin receptors inhibit strain-induced DNA synthesis. To begin identification of the integrin receptor( $\mathrm{s}$ ) involved in transducing the mechanical signal, we screened existing function-blocking antibodies to integrins of the fibronectin/vitronectin receptor families for crossreactivity with the rat VSM cells used in these studies. Using FACS $^{\star}$ we identified an $\mathrm{mAb}$, clone P1F6, to the human vitronectin receptor, $\alpha_{\mathrm{v}} \beta_{5}$, that cross-reacts with rat cells (Fig. 8 ). Additionally, the cells were found to cross-react with a nonfunction-blocking antibody to the human $\alpha_{\mathrm{v}}$ integrin subunit (H5P10).

Finally, we asked whether the $\alpha_{\mathrm{v}} \beta_{5}$ antibody would interfere with the response to mechanical strain. Control cells exposed to $48 \mathrm{~h}$ of mechanical strain exhibited a 3.2-fold increase in $\left[{ }^{3} \mathrm{H}\right]$ thymidine incorporation; cells treated with random IgG responded similarly. However, thymidine incorporation after strain in cells treated with anti- $\alpha_{\mathrm{v}} \beta_{5}$ was reduced by $90 \%$ (Fig. $9 A$ ). A rat anti- $\beta_{3}$ antibody (28) also reduced the mitogenic response to strain by $\sim 90 \%$. A non-function-blocking antibody which recognizes rat $\alpha_{\mathrm{v}}$ (H5P10) did not block the response to strain (Fig. $9 \mathrm{~B}$ ). Moreover an antibody to rat $\beta_{1}$

Table IV. Effect of RGD Peptide on Secretion of Growth Factors by Cells Exposed to Strain

\begin{tabular}{|c|c|c|}
\hline \multirow[b]{2}{*}{ Condition } & No strain & Strain \\
\hline & \multicolumn{2}{|c|}{ Thymidine incorporation } \\
\hline & \multicolumn{2}{|c|}{ cpm } \\
\hline Control & $27,942 \pm 2,238$ & $42,683 \pm 3,825$ \\
\hline GRGDTP & $20,648 \pm 4,821$ & $23,147 \pm 3,400$ \\
\hline
\end{tabular}

Cells were incubated with GRGDTP $(100 \mu \mathrm{g} / \mathrm{ml})$ as indicated and were subjected to mechanical strain or no strain for $48 \mathrm{~h}$. Medium was collected and transferred to experimental cells that had not been subjected to strain. $24 \mathrm{~h}$ later, thymidine incorporation was determined. Data are mean $\pm \mathrm{SE}$ of triplicate determinations.
(29) did not significantly blunt the response to strain. None of the antibodies we tested significantly altered the mitogenic response to PDGF (data not shown). Thus the response to mechanical strain appears to be mediated through specific fibronectin/vitronectin receptors, including $\alpha_{\mathrm{v}} \beta_{5^{-}}$and $\beta_{3}$-containing integrins.

\section{Discussion}

Mechanical deformation is a prominent feature of the environment of VSM cells in vivo and may play an important role both in developmental and pathological changes in the structure of

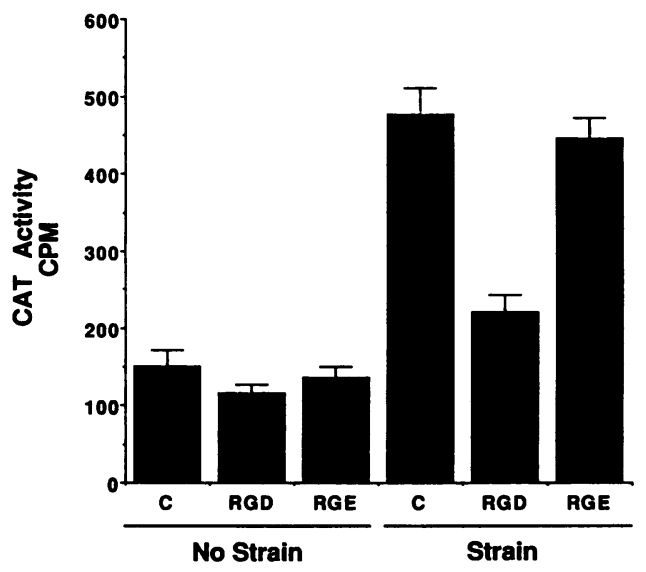

Figure 7. RGD peptides block strain-induced PDGF-A chain promoterdriven CAT activity. VSM cells were cotransfected (see Methods) with a PDGF-A chain promoter ( $890 \mathrm{bp}$ ) CAT construct and Rous Sarcoma Virus- $\beta$-gal. After $24 \mathrm{~h}$ of recovery, cells were exposed to either GRGDTP $(100 \mathrm{mg} / \mathrm{ml})$ or GRGESP $(100 \mathrm{mg} / \mathrm{ml})$ and to cyclic strain for $24 \mathrm{~h}$. The lysates were harvested, assayed for $\beta$-galactosidase and CAT activities, and CAT normalized to $\beta$-galactosidase. Data presented as mean $\pm \mathrm{SE}$ for quadruplicate determinations in one of two similar experiments. 


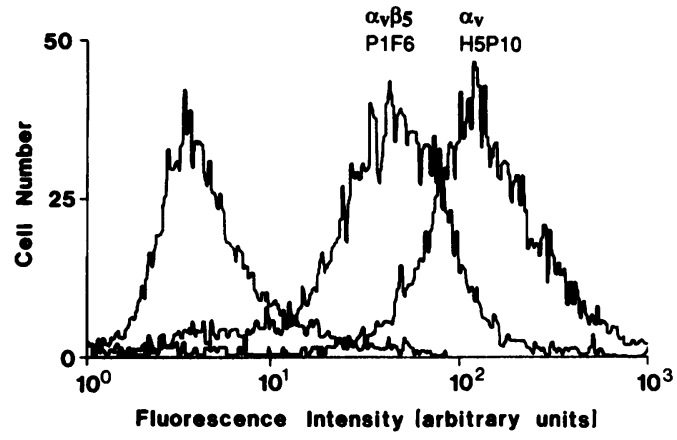

Figure 8. Screening of integrin antibodies by FACS ${ }^{\bullet}$ analysis. Rat VSM cells were incubated with no antibody or with integrin antibodies P1F6 or H5P10. After incubation with secondary phycoerythrin-conjugated anti-mouse antibody, they were prepared for flow cytometry as described in Methods. Histograms show distribution of cells that interact with each antibody. The $\mathrm{x}$-axis corresponds to fluorescence intensity (arbitrary units plotted on a logarithmic scale), and the y-axis corresponds to cell number.

blood vessels. We have previously reported that in neonatal VSM cells, cyclic mechanical strain causes an increase in DNA synthesis via the autocrine production of PDGF (7). The present study was designed to learn more about the detection and signaling of mechanical forces.

The experiments reported in this study show that in VSM cells, the mitogenic response to mechanical strain is conferred through specific interactions with the extracellular matrix. Cells plated on silicone elastomer coated with collagen, fibronectin, or vitronectin increased DNA synthesis in response to mechanical strain, while cells plated on laminin, elastin, poly-L-lysine, or no coating responded minimally or not at all (Fig. 1). Although basal rates of DNA synthesis varied greatly on these various matrix proteins, there was no obvious correlation between basal thymidine incorporation on any given matrix protein and the response to strain on that protein. In addition, the failure of laminin to elicit a mitogenic response to strain cannot be explained by a nonspecific interference with mitogenic responses. Cells cultured on laminin failed to respond to strain but responded normally to PDGF and thrombin. More importantly, cells cultured on laminin (Fig. 2) were capable of responding to strain when the coating also contained small quantities of vitronectin.

The role of specific ECM proteins in conferring a response to strain was further assessed by exposing cells to these proteins in soluble form. When soluble, these proteins cannot confer information about surface deformation. When cells adhered to collagen were exposed to soluble fibronectin, the strain response was obliterated as fibronectin concentration increased. On the other hand, soluble laminin had no effect on the mitogenic response to strain. These data suggest that fibronectin, but not laminin, actually interferes with the detection of mechanical strain when presented to the cell in the medium instead of being fixed to the deforming substrate.

The state of extracellular matrix proteins is important in determining biological responses in other systems. For example, Werb and co-workers showed that immobilized RGD peptides or fibronectin fragments induce metalloproteinases by synovial fibroblasts, while intact fibronectin results in low expression of metalloproteinase $(10,30)$. Schwartz showed that insoluble,
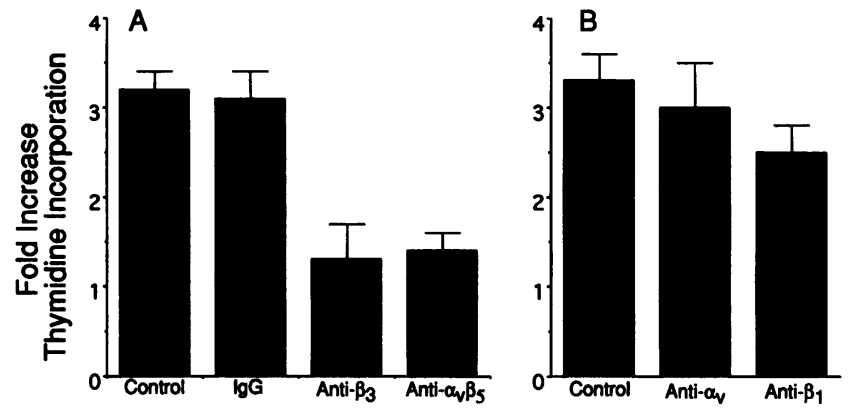

Figure 9. Antibodies to $\alpha_{\mathrm{v}} \beta_{5}$ and $\beta_{3}$ integrins block mitogenic response to strain. Confluent VSM cells on collagen-coated silicone elastomer membranes were placed in quiescence medium (see Methods) for 72 h. (A) Cells were treated with no antibody (Control), $10 \mu \mathrm{g} / \mathrm{ml} \mathrm{IgG}$ $(I g G), 10 \mu \mathrm{g} / \mathrm{ml}$ anti-rat $\beta_{3}\left(\right.$ anti- $\left.\beta_{3}\right)$ or 1:20 dilution of hybridoma medium containing the P1F6 anti-human $\alpha_{\mathrm{v}} \beta_{5}\left(\right.$ Anti- $\left.\alpha_{v} \beta_{5}\right)$ and subjected to $48 \mathrm{~h}$ of mechanical strain. $(B)$ Cells were incubated with a 1:20 dilution of hybridoma medium containing the non-functionblocking H5P10 anti-human $\alpha_{\mathrm{v}}\left(A n t i-\alpha_{v}\right)$, or $10 \mu \mathrm{g} / \mathrm{ml}$ of IgM antibody $\mathrm{Ha} 2 / 5$ against rat $\beta_{1}\left(\right.$ Anti- $\left.\beta_{1}\right)$. Fold increase in $\left[{ }^{3} \mathrm{H}\right]$ thymidine incorporation was measured as described in Methods. The data are the mean \pm SE for triplicate determinations of one of two similar experiments.

but not soluble, fibronectin activates $\mathrm{Na} / \mathrm{H}$ exchange by clustering and immobilizing integrins (31).

These data taken together suggest that specific extracellular matrix proteins, including fibronectin and vitronectin, are involved in the cellular detection of mechanical strain. Preliminary data examining the induction of smooth muscle myosin in response to strain suggests that the matrix protein $(\mathrm{s})$ responsible for conferring a given response to strain may not be invariate. Laminin, which does not confer a mitogenic response to strain, may participate in altered expression of myosin isoforms after mechanical strain (Reusch, H. P., H. Wagdy, R. Reusch, E. Wilson, and H. E. Ives, submitted for publication).

The concept that cell-matrix interactions are involved in determination of VSM cell phenotype has also been examined in the past. Hedin and co-workers showed that primary cultures of VSM cells plated onto either fibronectin or type I collagen grow more rapidly and express diminished smooth muscle $\alpha$ actin than cells plated on laminin or type IV collagen (32-34).

Further work was aimed at determining whether the response to mechanical strain was simply a reflection of adhesion to the various substrate molecules. Cells plated on poly-L-lysine or silicone elastomer without coating most likely did not respond because they remained rounded, lacking extensive contacts with the surface being deformed. On the other hand, cells plated on elastin, laminin, collagen, or fibronectin all adhered (Table III) and spread (Fig. 3) similarly yet showed dramatic differences in the response to mechanical strain (Fig. 1). This finding suggests that the cell-matrix interactions involved in detection of mechanical strain are more limited than the interactions involved in adherence and spreading. Along these lines, Clyman and co-workers found that adhesion of VSM cells to many substrates requires a $\beta_{1}$ integrin subunit, while migration specifically requires occupancy of $\alpha_{\mathrm{v}} \beta_{3}$ integrins (35). Using endothelial cells, Schwartz and Denninghoff found that $\alpha_{\mathrm{v}}$ integrins are involved in calcium signaling but play only a minor role in adhesion (36). These data from several systems indicate that the cell-matrix interactions involved in signaling biological responses may differ from those involved in adhesion. 
In our studies, fibronectin and vitronectin conferred the largest response to mechanical strain. This finding suggests that the primary method of sensing mechanical strain may be through interaction of fibronectin/vitronectin with specific integrin receptors. There is a high degree of redundancy of the integrin receptors for extracellular matrix ligands. For example, fibronectin can bind to integrins $\alpha_{3} \beta_{1}, \alpha_{4} \beta_{1}, \alpha_{5} \beta_{1}, \alpha_{\mathrm{v}} \beta_{1}, \alpha_{\mathrm{v}} \beta_{3}$, $\alpha_{\mathrm{v}} \beta_{5}$, and $\alpha_{\mathrm{v}} \beta_{6}$ (37). Vitronectin has been shown to bind to $\alpha_{\mathrm{v}} \beta_{1}, \alpha_{\mathrm{v}} \beta_{3}, \alpha_{\mathrm{v}} \beta_{5}(38)$. Because both fibronectin and vitronectin confer a response to mechanical strain, our initial screening of integrins has centered on the subset of molecules thought to bind these proteins.

Most of the currently available function-blocking integrin antibodies were raised against human proteins and do not crossreact with the rodent forms. There are however, some antihuman integrin antibodies that do cross-react with rat integrins. We found mAbs to $\alpha_{\mathrm{v}} \beta_{5}$ (P1F6) and $\alpha_{\mathrm{v}}$ (H5P10) cross-reacted with rat VSM cells (Fig. 7). Liaw and co-workers found that rat VSM cells also express $\alpha_{\mathrm{v}} \beta_{3}$ (39). Function-blocking integrin antibodies were used to interfere with the mitogenic response to mechanical strain. Both $\alpha_{\mathrm{v}} \beta_{5}$ and $\beta_{3}$ antibodies almost completely blocked this response, while the non-function-blocking $\alpha_{\mathrm{v}}$ antibody H5P10 did not significantly affect the response to strain. The virtually complete blockade of the strain response by both anti- $\alpha_{\mathrm{v}} \beta_{5}$ and anti- $\beta_{3}$ antibodies may be explained in several ways. First, the anti- $\beta_{3}$ antibody may cross-react with $\beta_{5}$. Alternatively, the strain response could require participation by both integrins. In this regard, it is interesting that an antibody to the most prevalent $\beta$ chain $\left(\beta_{1}\right)$ caused only partial inhibition of the strain response, suggesting that this $\beta$ chain may not be of major importance in conferring the mitogenic response to strain. In view of the limited availability of reagents for rat integrins, these studies may give only a partial view of the role of integrins in mechanical signaling. However, taken in conjunction with the data obtained with various ECM proteins (Figs. 1-4), they clearly implicate the $\alpha_{\mathrm{v}}$ family of fibronectin/ vitronectin receptors in conferring mitogenic responses to mechanical forces.

To further demonstrate that occupancy of specific matrix receptors is involved in the detection of strain, RGD peptides were added to cells while they were subjected to mechanical strain (Figs. 5-7). GRGDTP $(50-100 \mu \mathrm{g} / \mathrm{ml})$ completely blocked strain-induced DNA synthesis while the inactive GRGESP had no effect. The failure of cells to undergo a mitogenic response to strain in the presence of RGD peptides could be due to altered secretion of PDGF or to an altered response to the secreted PDGF. Lin and Grinnell showed decreased PDGFinduced receptor autophosphorylation in cells on relaxed collagen matrices compared with stressed collagen gels (40). In our system, cells exposed to GRGDTP still respond to PDGF (Fig. $5 B$ ), but conditioned medium from strained cells treated with GRGDTP was not mitogenic. Furthermore, GRGDTP inhibited the induction by strain of a PDGF-A chain promoter CAT construct. Thus, the extracellular matrix is responsible for conferring the signal(s) needed to enhance growth factor expression after mechanical strain.

The data presented in this study suggest that cells sense mechanical strain through interaction of integrin receptors in the plasma membrane with specific matrix RGD sites fixed to the moving substrate. Soluble RGD, fibronectin, and certain antiintegrin antibodies disrupt this specific interaction and prevent detection of mechanical strain without disrupting adhesion.
It is possible that detection of motion and subsequent signal generation involves movement of cytoskeletal elements bound to integrins (19). Work is currently under way to further characterize specific integrins and cytoskeletal elements involved in the detection and signaling of mechanical strain.

\section{Acknowledgments}

We thank Drs. Dean Sheppard and Tucker Collins for supplying essential reagents and Drs. Caroline Damsky and Dean Sheppard for critical reading of the manuscript.

This work was supported by National Institutes of Health grant HL41210, grants from the Research Evaluation and Allocation Committee and Academic Senate research committees of the University of California, San Francisco, and, during the tenure by H. E. Ives, an Established Investigator award from the American Heart Association. K. Sudhir was supported by a C. J. Martin fellowship of the National Health and Medical Research Council of Australia and funds from the Cardiac Research foundation (University of California, San Francisco)

\section{References}

1. Langille, B. L. 1993. Remodeling of developing and mature arteries: endothelium, smooth muscle and matrix. J. Cardiovasc. Pharmacol. 21(Suppl.1): S11-S17.

2. Folkow, B. 1990. The "structural factor" in hypertension. In Hypertension: Pathophysiology, Diagnosis, and Management. J. H. Laragh and B. M. Brenner, editors. Raven Press, Ltd., New York. 565-581.

3. Folkow, B., G. Grimby, and O. Thulesius. 1958. Adaptive structural changes of the vascular wall in hypertension and their relationship to control of peripheral resistance. Acta Physiol. Scand. 44:255-272.

4. Banes, A. J., J. Gilbert, D. Taylor, and O. Monbureau. 1985. A new vacuumoperated stress-providing instrument that applies static or variable duration cycle tension or compression to cells in vitro. J. Cell Sci. 75:35-42.

5. Banes, A. J., G. W. Link, J. W. Gilbert, R. T. S. Tay, and O. Monbureau 1989. Culturing cells in a mechanically active environment. Am. Biotechnol. Lab. 8:12-22.

6. Sumpio, B. E., A. J. Banes, M. Buckley, and G. Johnson. 1988. Alterations in aortic endothelial cell morphology and cytoskeletal protein synthesis during cyclic tensional deformation. J. Vasc. Surg. 7:130-138.

7. Wilson, E., Q. Mai, K. Sudhir, R. H. Weiss, and H. E. Ives. 1993. Mechanical strain induces growth of vascular smooth muscle cells via autocrine action of PDGF. J. Cell Biol. 123:741-747.

8. Sudhir, K., E. Wilson, K. Chatterjee, and H. E. Ives. 1993. Mechanical strain and collagen potentiate mitogenic activity of angiotensin II in rat vascular smooth muscle cells. J. Clin. Invest. 92:3003-3007.

9. Reusch, H. P., H. Wagdy, and H. E. Ives. 1994. Mechanical strain induces expression of smooth muscle myosin in cultured vascular smooth muscle cells. J. Am. Soc. Nephrol. 5:549a. (Abstr.)

10. Werb, Z., P. M. Tremble, O. Behrendtsen, E. Crowley, and C. H. Damsky 1989. Signal transduction through the fibronectin receptor induces collagenase and stromelysin gene expression. J. Cell Biol. 109:877-889.

11. Resnick, N., T. Collins, W. Atkinson, D. T. Bonthron, C. F. J. Dewey, and M. A. J. Gimbrone. 1993. Platelet-derived growth factor B chain promote contains a cis-acting fluid shear-stress-responsive element. Proc. Natl. Acad. Sci. USA. 90:4591-4595.

12. Wiersbitzky, M., I. Mills, B. E. Sumpio, and H. Gewirtz. 1994. Chronic cyclic strain reduces adenylate cyclase activity and stimulatory $\mathbf{G}$ protein subunit levels in coronary smooth muscle cells. Exp. Cell Res. 210:52-55.

13. Letsou, G. V., O. Rosales, S. Maitz, A. Vogt, and B. E. Sumpio. 1990 Stimulation of adenylate cyclase activity in cultured endothelial cells subjected to cyclic stretch. J. Cardiovasc. Surg. 31:634-639.

14. Mills, I., G. Letsou, J. Rabban, B. E. Sumpio, and H. Gewirtz. 1990 Mechanosensitive adenylate cyclase activity in coronary vascular smooth muscle cells. Biochem. Biophys. Res. Commun. 171:143-147.

15. Brophy, C. M., I. Mills, O. Rosales, C. Isales, and B. E. Sumpio. 1993. Phospholipase C: a putative mechanotransducer for endothelial cell response to acute hemodynamic changes. Biochem. Biophys. Res. Commun. 190:576-581.

16. Brighton, C. T., B. J. Sennett, J. C. Farmer, J. P. Iannotti, C. A. Hansen, J. L. Williams, and J. Williamson. 1992. The inositol phosphate pathway as mediator in proliferative response of rat calvarial bone cells to cyclical biaxial mechanical strain. J. Orthop. Res. 10:385-393.

17. Wirz, H. R. W., and L. G. Dobbs. 1990. Calcium mobilization and exocytosis after one mechanical stretch of lung epithelial cells. Science (Wash. DC). 250:1266-1269. 
18. Ingber, D. 1991. Integrins as mechanochemical transducers. Curr. Opin. Cell Biol. 3:841-848.

19. Wang, N., J. P. Butler, and D. E. Ingber. 1993. Mechanotransduction across the cell surface and through the cytoskeleton. Science (Wash. DC). 260:1124-1127.

20. Davies, P. F., A. Robotewskyi, and M. L. Griem. 1994. Quantitative studies of endothelial cell adhesion: directional remodeling of focal adhesion sites in response to flow forces. J. Clin. Invest. 93:2031-2038.

21. Weinacker, A., A. Chen, M. Agrez, R. I. Cone, S. Nishimura, E. Wayner R. Pytela, and D. Sheppard. 1994. Role of the integrin $\alpha \mathrm{v} \beta 6$ in cell attachment to fibronectin. Heterologous expression of intact and secreted forms of the receptor. J. Biol. Chem. 269:6940-6948.

22. Jones, P. A. T., T. Scott-Burden, and W. Gevers. 1979. Glycoprotein, elastin, and collagen secretion by rat smooth muscle cells. Proc. Natl. Acad. Sci. USA. 76:353-357.

23. Bolton, A. E., and W. M. Hunter. 1973. The labeling of proteins to high specific radioactivities by conjugation to a ${ }^{125}$ I-containing acylating agent. Biochem. J. 133:529-539.

24. Gashler, A. L., D. T. Bonthron, S. L. Madden, F. J. Rauscher, T. Collins, and V. P. Sukhatme. 1992. Human platelet-derived growth factor A chain is transcriptionally repressed by the Wilms tumor suppressor WT1. Proc. Natl. Acad. Sci. USA. 89:10984-10988.

25. Lopta, M. A., D. W. Cleveland, and B. Sollner-Webb. 1984. High-level expression of a chloramphenicol acetyltransferase gene by DEAE-dextran-mediated DNA transfection coupled with a dimethylsulfoxide or glycerol shock treatment. Nucleic Acids Res. 12:5707-5717.

26. Sleigh, M. J. 1986. A nonchromatographic assay for expression of the chloramphenicol acetyltransferase gene in eucaryotic cells. Anal. Biochem. 156:251-256

27. Ruoslahti, E., and M. D. Pierschbacher. 1987. New perspectives in cell adhesion: RGD and integrins. Science (Wash. DC). 238:491-497.

28. Helfrich, M. H., S. A. Nesbitt, and M. A. Horton. 1992. Integrins on rat osteoclasts: characterization of two monoclonal antibodies (F4 and F11) to rat B3. J. Bone Miner. Res. 7:345-351.
29. Mendrick, D. L., and D. M. Kelly. 1993. Temporal expression of VLA-2 and modulation of its ligand specificity by rat glomerular epithelial cells in vitro. Lab. Invest. 69:690-702.

30. Werb, Z., P. Tremble, and C. H. Damsky. 1990. Regulation of extracellular matrix degradation by cell-extracellular matrix interactions. Cell Differ. Dev. 32:299-306.

31. Schwartz, M. A. 1993. Signaling by integrins: implications for tumorigenesis. Cancer Res. 53:1503-1506.

32. Hedin, U., and J. Thyberg. 1987. Plasma fibronectin promotes modulation of arterial smooth muscle cells from contractile to synthetic phenotype. Differentiation. 33:239-246.

33. Hedin, U., B. A. Bottger, E. Forsberg, S. Johansson, and J. Thyberg. 1988. Diverse effects of fibronectin and laminin on phenotypic properties of cultured arterial smooth muscle cells. J. Cell Biol. 107:307-319.

34. Hedin, U., M. Sjolund, A. Hultgardh-Nilsson, and J. Thyberg. 1990 Changes in expression and organization of smooth-muscle-specific $\alpha$-actin during fibronectin-mediated modulation of arterial smooth muscle cell phenotype. Differentiation. 44:222-231.

35. Clyman, R. I., F. Mauray, and R. H. Kramer. 1992. $\beta_{1}$ and $\beta_{3}$ integrins have different roles in the adhesion and migration of vascular smooth muscle cells on extracellular matrix. Exp. Cell Res. 200:272-284.

36. Schwartz, M. A., and K. Denninghoff. 1994. $\alpha \mathrm{v}$ integrins mediate the rise in intracellular calcium in endothelial cells on fibronectin even though they play a minor role in adhesion. J. Biol. Chem. 269:11133-11137.

37. Hynes, R. O. 1992. Integrins: versatility, modulation, and signaling in cell adhesion. Cell. 69:11-25.

38. Felding-Habermann, B., and D. A. Cheresh. 1993. Vitronectin and its receptors. Curr. Opin. Cell Biol. 5:864-868.

39. Liaw, L., M. Almeida, C. E. Hart, S. M. Schwartz, and C. M. Giachelli. 1994. Osteopontin promotes vascular cell adhesion and spreading and is chemotactic for smooth muscle cells in vitro. Circ. Res. 74:214-224.

40. Lin, Y.-C., and F. Grinnell. 1993. Decreased level of PDGF-stimulated receptor autophosphorylation by fibroblasts in mechanically relaxed collagen matrices. J. Cell Biol. 122:663-672. 